\title{
Gambaran Status Gizi Pasien Diabetes Melitus Tipe 2 Berdasarkan Antropometri
}

\author{
Mukhyarjon $^{1 *}$, Imelda Tresia Pardede ${ }^{2}$, Wulan Amelia Putri ${ }^{3}$
}

\begin{abstract}
Nutritional status is an expression of a state of balance between intake of nutrient and their requirements. Diabetes mellitus is one of the comorbid diseases of obesity due to insulin resistance. This has a negative impact on the tissue causing complications, especially central obesity because it is more resistant to the effects of insulin than adipocytes in other areas. This study aims to describe the nutritional status of people with type 2 diabetes based on anthropometry. This research was a descriptive study with a cross sectional approach using purposive sampling method on 62 respondents. The data collected were anthropometric examinations, HbAlc, and questionnaires. Result of this study showed that most subjectswere aged between 45-65 years (64,5\%), mostly female (54,8\%). Most subject (75,8\%) being diabetic $\leq 5$ years and as many as $61,3 \%$ had HbAlc levels $\geq 7 \%$. The most prevalent diabetic drag used was metformin (69,4\%). From the anthropometric examination, it was found that the most nutritional status was obesity (54.85\%), with the most age $>45$ years (56.9\%), male gender (57.1\%), onset from type 2 diabetes $>65$ years (66,7\%), HbAlc levels $\geq 7 \%$ (55.3\%) and use of insulin with a percentage of 71,4\%. As many as 72,6\% subject had central obesity.
\end{abstract}

Keyword: Nutritional status, diabetes mellitus type 2, obesity

Perkembangan zaman yang terus maju diberbagai bidang dan peningkatan kemakmuran masyarakat, secara global terjadi transisi epidemiologis penyakit degeneratif yang mendominasi dibanding penyakit lainnya. Salah satu penyakit degeneratif yang prevalensinya terus meningkat adalah diabetes melitus (DM) terutama DM tipe 2. Peningkatan ini sejalan dengan kecenderungan masyarakat mengkonsumsi makanan cepat saji (fast food) yang umumnya mengandung tinggi lemak dan protein tetapi rendah karbohidrat kompleks khususnya serat. Hasil penelitian di RSU Sanglah Denpasar menunjukkan bahwa orang yang mempunyai kebiasaan konsumsi serat rendah dengan status gizi obesitas berisiko mengidap DM tipe 2 sebanyak 10,7 kali dan 4,9 kali pada orang yang memiliki kebiasaan mengonsumsi sumber protein hewani berlemak tinggi.

\footnotetext{
* Corresponding author: mukhyarjon@yahoo.com

KJFD Biokimia Fakultas Kedokteran Universitas Riau, Pekanbaru, Riau

2 KJFD Ilmu Gizi Fakultas Kedokteran Universitas Riau, Pekanbaru, Riau

3 Program Studi Kedokteran Fakultas Kedokteran Universitas Riau, Pekanbaru, Riau
}

Diabetes melitus umumnya dilatarbelakangi oleh adanya gangguan sekresi dan resistensi insulin yang berkaitan dengan kondisi komorbid seperti hipertensi, dislipidemia dan obesitas. Populasi dengan indeks massa tubuh (IMT) lebih atau sama dengan $25 \mathrm{~kg} / \mathrm{m}^{2}$ memiliki risiko hipertensi lebih tinggi. Penelitian di RSU Sanglah Denpasar membuktikan bahwa orang yang hipertensi berisiko 3,7 kali lebih besar untuk mengidap DM tipe 2 . Penelitian lain membuktikan bahwa keterkaitan antara obesitas dengan sindroma metabolik. Risiko untuk mengalami komorbid berat dijumpai pada orang laki-laki obes yang memiliki lingkar pinggang (LP) $\geq 90 \mathrm{~cm}$ dan perempuan $\geq 80 \mathrm{~cm}$. Buruknya pengendalian kadar glukosa darah, tekanan darah dan kolesterol pasien DM tipe 2 berkaitan dengan kelebihan berat badan. Adapun hasil penelitian di RSU Gunung Jati Cirebon menunjukkan bahwa pengendalian kadar glukosa darah pengidap DM tipe 2 berkaitan dengan pola makan, yaitu asupan karbohidrat, lemak, serta gula dan hasil olahannya. ${ }^{3,4}$

Menurut Perkumpulan Endokrinologi Indonesia (PERKENI) penatalaksanaan diabetes meliputi edukasi, terapi nutrisi medis, latihan 
jasmani dan farmakologi yang dikenal dengan istilah 4 pilar. Terapi empat pilar ini diperlukan untuk menunjang peningkatan kualitas hidup penyandang DM. Terapi nutrisi medis merupakan salah satu pengobatan utama untuk pasien DM yang bertujuan untuk memperbaiki kesehatan umum pasien, mempertahankan berat badan normal, mempertahankan kadar glukosa darah tetap stabil, memperbaiki profil lipid, meningkatkan sensitivitas reseptor insulin dan mencegah komplikasi akut atau kronik. Oleh sebab itu, perlu adanya pengukuran status gizi untuk melakukan terapi nutrisi medic. ${ }^{5,6}$

Status gizi adalah ekspresi dari keadaan keseimbangan antara asupan zat gizi dari makanan dengan kebutuhan zat gizi yang diperlukan untuk metabolisme tubuh yang di kategorikan menjadi status gizi kurang, normal dan lebih. Diabetes melitus merupakan salah satu penyakit komorbid obesitas akibat terjadi resistensi insulin. Hal ini berdampak buruk terhadap jaringan sehingga menimbulkan komplikasi terutama obesitas sentral karena lebih resisten terhadap efek insulin dibandingkan dengan adiposit di daerah lain. ${ }^{7}$

Keadaan gizi kurang menyebabkan seseorang rentan terkena penyakit infeksi oleh sebab itu status gizi yang tidak baik dan tidak terjaganya pengelolaan DM empat pilar dapat meningkatkan kejadian sindroma metabolik. Kondisi status gizi yang tidak ditangani dengan baik dapat meningkatkan risiko gizi kurang pada penderita DM. Kondisi malnutrisi berupa gizi kurang sering terjadi di rumah sakit baik rawat inap maupun rawat jalan. ${ }^{1}$ Menurut hasil penelitian Suryani menunjukkan bahwa penderita DM tipe 2 lebih banyak memiliki status gizi obesitas tingkat I yaitu sebesar 33,3\% dibandingkan dengan status gizi obesitas tingkat II sebesar 3,3\% hal ini sesuai dengan penelitian yang dilakukan sebelumnya oleh Adnan bahwa semakin tinggi indeks massa tubuh (IMT) seseorang maka semakin tinggi pula kadar glukosa dalam darahnya. Status gizi juga dipengaruhi oleh aktivitas fisik karena berperan dalam keseimbangan energi. Aktivitas fisik yang kurang dapat mengakibatkan naiknya berat badan jika asupan makanan melebihi energi yang dikeluarkan. ${ }^{10}$

\section{METODE}

Penelitian ini merupakan penelitian deskriptif dengan pendekatan cross sectional yangmenggunakan metode purposive sampling yang dilakukan pada satu waktu untuk mengetahui gambaran klinis dan status gizi DM tipe 2 berdasarkan antropometri. Lokasi pada penelitian ini diadakan di Balai Pauh Janggi Gedung Daerah Kota Pekanbaru dan klinik Prodia Pekanbaru pada November 2018 - Desember 2019. Populasi dalam penelitian ini adalah penderita DM tipe 2 di Kota Pekanbaru yang melakukan pengobatan di Rumah Sakit Awal Bros, Rumah Sakit Tabrani, Rumah Sakit Prima dan Rumah Sakit Ibnu Sina. Sampel dalam penelitian ini adalah seluruh pasien DM tipe 2 yang sudah didiagnosis oleh dokter spesialis penyakit dalam serta datang ke lokasi penelitian di Balai Pauh Janggi gedung daerah Pekanbaru pada Minggu, 18 November 2018 dan di Laboratorium Klinik Prodia pada tanggal Minggu, 15 September 2019. Analisis data dalam penelitian ini menggunakan analisis univariat. Hasil dari analisis dapat disajikan secara deskriptif dalam bentuk tabel distribusi frekuensi untuk menarik kesimpulan. Penelitian ini telah mendapatkan persetujuan etik dari Unit Etika Penelitian Kedokteran/Kesehatan Fakultas Kedokteran Universitas Riau, Nomor: B/175/UN.19.5.1.1.8/UEPKK/2020.

\section{HASIL}

Gambaran karakteristik pasien diabetes melitus tipe 2 berdasarkan umur, jenis kelamin, lama menderita DM, kadar HbA1c dan obat-obatan DM

Gambaran karakteristik pasien diabetes melitus tipe 2 berdasarkan umur, jenis kelamin, lama menderita DM, kadar HbA1c dan obat-obatan DM dapat dilihat pada tabel 1 . 
Tabel 1. Gambaran karakteristik pasien diabetes melitus tipe 2 berdasarkan umur, jenis kelamin, lama menderita DM, kadar HbA1c dan obat-obatan DM

\begin{tabular}{|c|c|c|}
\hline Karakteristik pasien & Jumlah (n) & Persentase (\%) \\
\hline $\begin{array}{l}\text { Umur } \\
18-44 \text { tahun } \\
45-65 \text { tahun } \\
>65 \text { tahun }\end{array}$ & $\begin{array}{l}10 \\
40 \\
12\end{array}$ & $\begin{array}{l}16,1 \\
64,5 \\
19,4\end{array}$ \\
\hline $\begin{array}{l}\text { Jenis kelamin } \\
\text { Laki-laki Perempuan }\end{array}$ & $\begin{array}{l}28 \\
34\end{array}$ & $\begin{array}{l}45,2 \\
54,8\end{array}$ \\
\hline $\begin{array}{l}\text { Lama menderita DM } \\
\leq 5 \text { tahun } \\
>5 \text { tahun }\end{array}$ & $\begin{array}{l}47 \\
15\end{array}$ & $\begin{array}{l}75,8 \\
24,2\end{array}$ \\
\hline $\begin{array}{l}\text { Kadar HbA1c } \\
<7 \% \\
\geq 7 \%\end{array}$ & $\begin{array}{l}24 \\
38\end{array}$ & $\begin{array}{l}38,7 \\
61,3\end{array}$ \\
\hline $\begin{array}{l}\text { Obat-obatan DM Metformin } \\
\text { Insulin+metformin } \\
\text { Insulin+sulfonilurea } \\
\text { Insulin }\end{array}$ & $\begin{array}{l}43 \\
11 \\
1 \\
7\end{array}$ & $\begin{array}{c}69,4 \\
17,7 \\
1,6 \\
11,3\end{array}$ \\
\hline Total & 62 & 100 \\
\hline
\end{tabular}

Pada tabel 1 didapatkan karakteristik subjek penelitian yang menderita DM tipe 2 berdasarkan usia paling banyak $>45$ tahun dengan persentase $82,3 \%$, jenis kelamin yang tersering adalah perempuan sebesar 54,8\%, untuk lama menderita DM yang tersering adalah $\leq 5$ tahun yaitu sebesar $75,8 \%$. Pada kadar HbA1c didapatkan sebagian besar tidak terkontrol sebanyak $61,3 \%$ dan pada penggunaan obat-obatan yang paling sering digunakan adalah metformin dengan persentase $69,4 \%$.

Distribusi frekuensi status gizi pasien DM tipe 2

Distribusi frekuensi status gizi pasien DM tipe 2 dapat dilihat pada tabel 2 .

Tabel 2. Distribusi frekuensi status gizi pasien DM tipe 2

\begin{tabular}{lcc}
\hline \multicolumn{1}{c}{ Status Gizi } & Jumlah (n) & Persentase (\%) \\
\hline Underweight & 0 & 0 \\
Normal & 11 & 17,7 \\
Overweight & 17 & 24,4 \\
Obesitas & 34 & 54,8 \\
\hline Total & $\mathbf{6 2}$ & $\mathbf{1 0 0}$ \\
\hline
\end{tabular}

Pada tabel 2 menunjukkan dari hasil penelitian 62 sampel didapatkan penderita DM tipe 2 mengalami obesitas dengan persentase tertinggi $54,8 \%$.
Distribusi frekuensi status gizi pasien DM tipe 2 berdasarkan umur, jenis kelamin, lama menderita DM , kadar HbA1c, dan obat-obatan DM

Distribusi frekuensi status gizi pasien DM tipe 2 berdasarkan umur, jenis kelamin, lama menderita DM, kadar HbA1c dan obat-obatan dapat dilihat pada tabel 3 . 
Tabel 3. Distribusi frekuensi status gizi pasien DM tipe 2 berdasarkan umur, jenis kelamin, lama menderita DM , kadar HbA1c, dan obat-obatan DM

\begin{tabular}{lcccc}
\hline Status gizi & $\begin{array}{c}\text { Normal } \\
\text { Normal }\end{array}$ & Over weight & Obesitas & Total \\
\cline { 2 - 5 } & $\mathbf{n}(\mathbf{\%})$ & $\mathbf{n}(\mathbf{\%})$ & $\mathbf{n}(\mathbf{\%})$ & $\mathbf{n}(\mathbf{\%})$ \\
\hline Umur & & & & \\
$18-44$ & $3(30)$ & $2(20)$ & $5(50)$ & $10(100)$ \\
$45-65$ & $8(20)$ & $11(27,5)$ & $21(52,5)$ & $40(100)$ \\
& & & & \\
$>65$ & $0(0)$ & $4(33,3)$ & $8(66,7)$ & $12(100)$ \\
Jenis kelamin & $6(21,4)$ & $6(21,4)$ & $16(57,1)$ & $28(100)$ \\
Laki-laki & $5(14,7)$ & $11(32,4)$ & $18(52,9)$ & $34(100)$ \\
Perempuan & $11(23,4)$ & $11(23,4)$ & $25(53,2)$ & $47(100)$ \\
Lama menderita DM & $0(0)$ & $6(40)$ & $9(60)$ & $15(100)$ \\
$\leq 5$ tahun & $3(12,5)$ & $8(33,3)$ & $13(54,2)$ & $24(100)$ \\
$>5$ tahun & $8(21,1)$ & $9(23,7)$ & $21(55,3)$ & $38(100)$ \\
Kadar HbA1c & & & & \\
$<7 \%$ & $9(20,9)$ & $11(25,6)$ & $23(53,5)$ & $43(100)$ \\
$\geq 7 \%$ & $1(9,1)$ & $4(36,4)$ & $6(54,5)$ & $11(100)$ \\
Obat-obatan & $0(0)$ & $1(100)$ & $0(0)$ & $1(100)$ \\
Metformin & $1(14,3)$ & $1(14,3)$ & $5(71,4)$ & $7(100)$ \\
Insulin+metformin & & &
\end{tabular}

Pada tabel 3 didapatkan bahwa obesitas tersering ditemukan pada kelompok usia $>65$ tahun dengan persentase $66,7 \%$. Obesitas lebih banyak ditemukan pada laki-laki dibanding perempuan. Berdasarkan lama menderita DM didapatkan bahwa obesitas tersering ditemukan pada subjek penelitian dengan durasi lama $\mathrm{DM}>5$ tahun dengan persentase $60 \%$. Berdasarkan kadar $\mathrm{HbA} 1 \mathrm{c}$ subjek penelitian yang memiliki kadar $\mathrm{HbA} 1 \mathrm{c}$ tidak terkontrol $\geq 7 \%$ mengalami obesitas tersering dengan persentase $55,3 \%$ sementara hanya sedikit yang berstatus nutrisi normal pada kadar $\mathrm{HbAlc}$ yang terkontrol dibandingkan dengan kadar $\mathrm{HbAlc}$ yang tidak terkontrol. Pada subjek penelitian yang menggunakan terapi insulin baik insulin saja ataupun insulin dengan kombinasi sulfonilurea lebih banyak mengalami overweight dan obesitas.

\section{Gambaran obesitas sentral pada pasien DM tipe 2 berdasarkan lingkar pinggang.}

Gambaran obesitas sentral pada penderita DM tipe 2 berdasarkan lingkar pinggang dapat dilihat pada tabel 4
Tabel 4 Gambaran status gizi pasien DM tipe 2 berdasarkan lingkar pinggang

\begin{tabular}{lcc}
\hline Lingkar pinggang & Jumlah (n) & Persentase (\%) \\
\hline Normal & 17 & 27,4 \\
Obesitas sentral & 45 & 72,6 \\
\hline Total & 62 & 100 \\
\hline
\end{tabular}

Hasil penelitian menunjukkan subjek penelitian mengalami obesitas sentral dengan persentase $72,6 \%$.

\section{PEMBAHASAN}

Gambaran karakteristik pasien Diabetes Melitus Tipe 2 berdasarkan umur, jenis kelamin, lama menderita DM, kadar HbA1c dan obat-obatan DM

Hasil penelitian ini menunjukkan bahwa sebagian besar subjek penelitian berusia 45-65 tahun dengan persentase $82,3 \%$. Penelitian ini sesuai dengan penelitian yang dilakukan oleh Harsari yang mendapatkan usia penderita DM tersering pada usia 
$>45$ tahun dengan persentase $84,61 \%$. Penelitian serupa juga didapatkan oleh penelitian Pardede bahwa kelompok usia yang paling sering menderita DM tipe 2 adalah kelompok usia 45-65 tahun dengan persentase $70,6, \% .8,11$

Salah satu faktor risiko terjadinya DM tipe 2 adalah umur $>45$ tahun karena terjadinya proses menua yang berlangsung sehingga mengakibatkan terjadinya perubahan anatomis, fisiologis dan biokimia dimulai dari tingkat sel hingga organ yang dapat mempengaruhi homeostasis. Komponen tubuh yang dapat berubah adalah sel $\beta$ pankreas yang mengalami penurunan yang progresif sehingga hormon yang dihasilkan sedikit dan menyebabkan rentan timbulnya DM. Selain itu pada usia tersebut kebanyakan orang telah mengalami obesitas dan penurunan aktivitas yang menyebabkan tubuh menjadi kurang peka terhadap insulin. ${ }^{12}$

Pada penelitian ini menunjukkan bahwa penderita DM tipe 2 yang berjenis kelamin perempuan lebih banyak dibandingkan jenis kelamin laki-laki dengan perenstase $54,8 \%$. Hal ini sesuai dengan penelitian yang dilakukan oleh Suryani yang menunjukkan bahwa prevalensi DM tipe 2 pada perempuan lebih tinggi dibandingkan dengan laki-laki yaitu $63,3 \%{ }^{8}$

Berdasarkan teori perempuan lebih banyak menderita DM tipe 2 karena secara fisik perempuan memiliki peluang dalam peningkatan IMT dan sindroma siklus menstruasi sehingga pada saat perimenopause dapat menyebabkandistribusi lemak tubuh menjadi lebih mudah terakumulasi akibat efek hormonal tersebut sehingga perempuan beresiko menderita DM tipe 2. ${ }^{9}$

Pada penelitian ini sebagian besar subjek penelitian memiliki riwayat lama $\mathrm{DM} \leq 5$ tahun dengan persentase $(51,6 \%)$. Hasil penelitian ini hampir sama dengan penelitian oleh penelitian Krismanita yang menunjukkan bahwa penderitia DM tipe 2 terbanyak berada pada kelompok $\leq 5$ tahun yaitu sebanyak $54 \%$. $^{13}$

Meskipun jumlah lama DM $\leq 5$ tahun lebih banyak dibandingkan dengan lama $\mathrm{DM}>5$ tahun namun tidak bisa dikatakan bahwa pasien DM ini tidak memiliki komplikasi kronis karena banyak faktor yang mempengaruhi terjadinya komplikasi kronis seperti kontrol gula darah, usia, IMT dan lainnya. ${ }^{14,15}$
Pada penelitian ini kadar $\mathrm{HbAlc}$ pada pasien DM tipe 2 yang paling sering ditemukan adalah $\geq 7 \%$ dengan persentase $61,3 \%$. Penelitian ini serupa dengan penelitian yang dilakukan oleh Utomo yang juga mendapatkan pasien DM tipe 2 memiliki kadar $\mathrm{HbA} 1 \mathrm{c}$ tidak terkontrol $\geq 7 \%$ dengan persentase $77,3 \% .{ }^{16}$ Hasil penelitian ini menunjukkan bahwa sebagian besar penderita memiliki kadar gula darah tidak terkontrol. Hal ini dapat terjadi akibat gaya hidup yang kurang baik, asupan kalori yang berlebihan dan pengobatan yang tidak adekuat. ${ }^{3}$

Konsumsi obat DM pada penelitian ini yang sering digunakan adalah metformin dengan jumlah $69,4 \%$. Penelitian serupa juga didapatkan oleh Madelina penggunaan metformin sebesar $39,13 \%$. ${ }^{17}$ Pemberian metformin merupakan pilihan pertama pada sebagian besar kasus DM tipe 2 karena merupakan obat yang tersedia dalam jumlah besar di fasilitas kesehatan dan lebih ekonomis. Penggunaan metformin tidak merangsang sekresi insulin sehingga tidak meyababkan hipoglikemi dan peningkatan berat badan 6

\section{Distribusi frekuensi status gizi penderita DM tipe 2}

Hasil penelitian ini didapatkan distribusi frekuensi status nutrisi penderita DM tipe 2 yang paling sering adalah obesitas dengan persentase $54,8 \%$. Penelitian oleh Chandra juga mendapatkan hasil dengan persentase obesitas tersering yaitu $96 \%$.

Obesitas disebabkan oleh asupan nutrisi berlebih secara terus menerus yang menyebabkan simpanan lemak menjadi berlebih pada tubuh. Jaringan lemak tersebut merupakan suatu jaringan endokrin aktif yang melepaskan sitokin-sitokin adiposa. Sitokin akan mengganggu jalur persinyalan insulin yang menyebabkan terjadinya resistensi insulin. 18

\section{Distribusi frekuensi status gizi penderita DM tipe 2 berdasarkan umur, jenis kelamin, lama menderita DM, kadar HbA1c, dan obat-obatan DM}

Berdasarkan umur bahwa subjek penelitian lebih sering mengalami obesitas pada usia $>65$ tahun dengan persentase $66,7 \%$. Hasil penelitian 
Somantri juga mendapatkan status gizi obesitas pada lansia tersering dengan persentase $27,6 \%$. Hal ini dikarenakan aktivitas fisik yang sudah mulai berkurang dan pola makan yang tidak seimbang. Seiring dengan bertambahnya usia kebutuhan zat gizi karbohidrat dan lemak umumnya lebih rendah karena adanya penurunan metabolisme basal. Proses metabolisme yang menurun pada usia lanjut akan berisiko mengakibatkan kegemukan karena terjadi penurunan aktivitas fisik maka kalori yang berlebih akan diubah menjadi lemak sehingga mengakibatkan kegemukan. Proses menua menyebabkan proporsi lemak dan otot dalam tubuh berubah. 19

Pada penelitian ini obesitas terbanyak didapatkan pada jenis kelamin laki-laki 57,1\% dan perempuan $52,9 \%$. Hasil penelitian Septina juga mendapatkan obesitas lebih sering ditemukan pada laki-laki dengan persentase $67,1 \%$ dan perempuan dengan persentase $32,9 \%$. Hal ini dapat disebabkan karena asupan kalori pada laki- laki lebih banyak dibanding perempuan serta kurangnya aktivitas fisik. $^{20}$

Pada penelitian ini didapatkan obesitas terbanyak dialami oleh penderita DM tipe 2 dengan durasi $>5$ tahun dengan persentase $60 \%$. Penelitian yang dilakukan oleh Sasangko juga mendapatkan obesitas terbanyak pada durasi $\mathrm{DM}>5$ tahun namun lama menderita DM tidak mendapatkan adanya korelasi bermakna antara lama DM dengan IMT. 21

Pada penelitian ini didapatkan obesitas lebih sering pada kadar $\mathrm{HbA} 1 \mathrm{c} \geq 7 \%$ dengan persentase 55,3\%. Penelitian oleh Wulandari juga mendapatkan bahwa obesitas lebih sering ditemukan pada $\mathrm{HbAlc} \geq 7 \%$. Hal ini terjadi akibat kurang optimalnya pengendalian DM tipe 2 seperti intake makanan berlebih dan aktivitas fisik yang kurang yang dapat menyebabkan kurangnya pembakaran energi oleh tubuh sehingga kelebihan energi dalam tubuh akan disimpan dalam bentuk lemak. ${ }^{22}$ Pada penelitian ini didapatkan bahwa pada obesitas ataupun overweight banyak ditemukan pada pasien yang menggunakan insulin baik insulin saja ataupun insulin dengan kombinasi sulfonilurea. Penelitian yang dilakukan oleh Min mendapatkan bahwa pasien yang mennggunakan terapi kombinasi insulin dengan sulfonil urea lebih sering mengalami obesitas dengan persentase $97,1 \%$. Hal ini sesuai dengan teori yang menyatakan bahwa penggunaan insulin ataupun sulfonil urea memiliki efek samping peningkatan berat badan. 23

\section{Gambaran status gizi pasien DM tipe 2 berdasarkan lingkar pinggang}

Hasil penelitian ini menunjukkan bahwa responden dengan obesitas sentral sebanyak $72,6 \%$. Hal ini sesuai dengan penelitian Pagehgiri yang mendapatkan obesitas sentral sebanyak 80,3\%. Pada obesitas sentral dapat meningkatkan pelepasan asam lemak ke sirkulasi darah. Pelepasan asam lemak secara berlebihan akan meningkatkan produksi glukosa dan trigliserida. Peningkatan tersebut akan meningkatkan sekresi insulin pada pankreas sehingga menyebabkan hiperinsulinemia. ${ }^{24}$

Obesitas sentral dapat terjadi karena berbagai faktor seperti umur, jenis kelamin, hormon, asupan nutrisi dan aktivitas fisik. Obesitas sentral yang terjadi berhubungan erat dengan peningkatan risiko sindroma metabolik. 24

\section{KESIMPULAN}

Gambaran karakteristik pasien DM tipe 2 berdasarkan umur yang terbanyak adalah 45-65 tahun dengan jenis kelamin perempuan, lama menderita DM terbanyak adalah $\leq 5$ tahun dengan kadar $\mathrm{HbA} 1 \mathrm{c} \geq 7 \%$ dan obat-obatan DM paling sering digunakan adalah metformin. Distribusi frekuensi status gizi DM tipe 2 terbanyak adalah obesitas yang ditemukan pada kelompok usia $>65$ tahun dengan jenis kelamin pada laki-laki, lama DM $>5$ tahun, kadar $\mathrm{HbAlc}>7 \%$ dan menggunakan insulin.

\section{DAFTAR PUSTAKA}

1. Suhaema, Asdie AH, Pangastuti R. Pengendalian status gizi, kadar glukosa darah dan tekanan darah melalui terapi gizi medis pada pasien diabetes mellitus ( DM) tipe 2 rawat jalan di RSU Mataram NTB 1. J Gizi Klinik Indonesia. 2010;7(2):48-57.

2. Wiardani N, Hadi H, Huriyati E. Pola makan dan obesitas sebagai faktor risiko DM tipe 2 di Rumah Sakit Denpasar. Gizi Klinik Indonesia.2007: 4(1):1-10. 
3. Awad N, Langi YA, Pandelaki K. Gambaran faktor resiko pasien diabetes melitus tipe ii di Poliklinik Endokrin bagian / SMF FK-UNSRAT RSU Prof. Dr R.D Kandou Manado periode Mei 2011-Oktober 2011. J e-Biomedik. 2011;1:45-9.

4. Bambrick H. Relationship betwen BMI, waist circumference, hypertention and fasting glucose: Rethinking risk factors in indigenous diabetes. Australian indigenous health bulletin. 2005.

5. Riset kesehatan dasar. Riset kesehatan dasar 2018. In: Laporan hasil riset kesehatan dasar nasional badan penelitian dan pengembangan kesehatan departemen kesehatan Republik Indonesia Jakarta. 2018.

6. Perkumpulan endokrinologi Indonesia. In: konsensus pengelolaan dan pencegahan diabetes melitus tipe 2 di Indonesia. 2018.

7. Limanan D, Prijanti AR. Hantaran sinyal leptin dan obesitas : hubungannya dengan penyakit kardiovaskuler. 2013;1(2).

8. Suryani, Rosdiana D, Chirstianto E. Gambaran status gizi pasien diabetes melitus tipe $2 \mathrm{di}$ bangsal penyakit dalam RSUD Arifin Achmad Provinsi Riau. JOM FK. 2016;3(1):3-8.

9. Adnan M, Mulyati T, Isworo JT. Hubungan indeks massa tubuh ( IMT ) dengan kadar gula darah penderita diabetes mellitus ( $\mathrm{dm}$ ) tipe 2 rawat jalan di RS Tugurejo Semarang. J gizi Univ Muhammadiyah Semarang. 2013;2(April):18-25.

10. Azitha M, Aprilia D, Ilhami YR. Artikel penelitian hubungan aktivitas fisik dengan kadar glukosa darah puasa pada pasien diabetes melitus yang datang ke poli klinik penyakit dalam rumah sakit M. Djamil Padang. Jurnal Kesehatan Andalas. 2018;7(3):400-4.

11. Jones M. The methodology of nutritional screening and assessment tools. J Hum Nutr Diet. 2002. 59-71.

12. Supariasa I, Bakri B, Fajar I. Penilaian status gizi. Vol.5. Jakarta: EGC; 2002.

13. Sa'pang M, Puilli D, Sitoayu L. Hubungan indeks masa tubuh dan rasio lingkar pinggang panggul (PRLPP) dengan kadar glukosa darah puasa pada penderita diabetes melitus tipe 2 di Puskesmas Kebayoran Lama. 2018;10(1).
14.Harahap M, Mochtar Y. Gambaran rasio lingkar pinggang pinggul, riwayat penyakit dan usia pada pegawai Polres Pekanbaru. Jurnal Kesehatan Masyarakat Andalas. 2016;140-4.

15. Sudoyo A, Setoyohadi B, Alwi I, Setiati S. Buku ajar ilmu penyakit dalam ed. 3 jakarta: pusat penerbit departemen penyakit dalam FK UI. 2006.

16. Susantiningsih T. Obesitas dan stres oksidatif obesity and oxidative stress. J Kesehatan Unila. 2015;5:9.

17.Jonas. Korelasi body mass index terhadap tekanan darah pada diabetes melitus tipe 2 di RSUD kabupaten Temanggung. Universitas Sanata Dharma; 2014.

18. Chandra AP, Ani LS. Indeks massa tubuh dan aktivitas fisik pada penderita diabetes mellitus tipe 2 di wilayah kerja puskesmas Manggis 1 tahun 20132013.

19. Somantri B. Hubungan indeks massa tubuh (IMT) dengan tekanan darah pada lansia di puskesmas melong asih cimahi (June 2013).

20. Septina T, Purba M, Hatriyanti Y. Studi validasi indeks massa tubuh dan rasio lingkar pinggang panggul terhadap profil lipid pada pasien rawat jalan di poli jantung RSUP Dr. Sardjito Yogyakarta. Jurnal gizi klinik Indonesia. 2010;10(1):34-40.

21. Sasongko A. Hubungan antara lama sakit dengan status antropometri pasien DM tipe 2 rawat jalan di RSUD dr. Saiful Anwar Malang. 2014;50-8.

22. Wulandari IAT, Herawati S, Wande N. Gambaran kadar $\mathrm{HbA} 1 \mathrm{c}$ pada pasien diabetes melitus tipe II di RSUP Sanglah periode Juli-Desember 2017. J Med udayana. 2020;9(1):73-5.

23. Min JY, Griffin MR, Hung AM, Grijalva CG, Greevy RA, Liu X, et al. Comparative effectiveness of insulin versus combination sulfonylurea and insulin : a Cohort Study of Veterans with Type 2 Diabetes. :638-46.

24.Pagehgiri ES, Irawati D, Josafat A. Hubungan antara rasio lingkar pinggang terhadap tinggi badan dengan glukosa darah puasa pada lansia. 2019;8(2):17-23 